\title{
Effects of diet on release of dissolved organic and inorganic nutrients by the copepod Acartia tonsa
}

\author{
Grace K. Saba*, Deborah K. Steinberg, Deborah A. Bronk \\ Virginia Institute of Marine Science, PO Box 1346, Gloucester Point, Virginia 23062, USA
}

\begin{abstract}
Acartia tonsa copepods are not limited to herbivory and can derive up to half their daily ration from predation on heterotrophic ciliates and dinoflagellates. The effects of an omnivorous diet on nutrient regeneration, however, remain unknown. In this study, we fed $A$. tonsa an exclusively carnivorous diet of either (1a) heterotrophic dinoflagellate Oxyrrhis marina or (1b) Gyrodinium dominans, (2) an exclusively herbivorous diet of Thalassiosira weissflogii diatoms, or (3) a mixed omnivorous diet. We measured the release rate, composition, and stoichiometry of dissolved organic carbon (DOC), dissolved organic phosphorus (DOP), and nitrogen (urea) in addition to the inorganic nutrients, ammonium $\left(\mathrm{NH}_{4}{ }^{+}\right)$and phosphate $\left(\mathrm{PO}_{4}{ }^{3-}\right)$. Despite similar ingestion rates among treatments, as well as similar $\mathrm{C}: \mathrm{N}$ ratios of food items, $A$. tonsa release rates of $\mathrm{DOC}$ and $\mathrm{NH}_{4}{ }^{+}$were highest while feeding on a carnivorous diet and lowest while feeding omnivorously. In contrast, urea, on average, was a higher portion of total nitrogen released in the mixed diet treatment (32 to 59\%). DOP release rates were only detectable in diets containing microzooplankton prey. Our results suggest that copepod diet plays an important role in determining the quantity and composition of regenerated $\mathrm{C}, \mathrm{N}$, and $\mathrm{P}$ available to phytoplankton and bacteria. Additionally, the uncoupling of ingestion and nutrient release rates and the variability in released ratios of dissolved $\mathrm{C}: \mathrm{N}: \mathrm{P}$ in our study suggests that stoichiometric models based exclusively on predator and prey $\mathrm{C}: \mathrm{N}$ and $\mathrm{N}: \mathrm{P}$ ratios may not be adequate in determining stoichiometry of total nutrient release.
\end{abstract}

KEY WORDS: Copepod $\cdot$ Diet $\cdot$ Food quality $\cdot$ Excretion $\cdot$ Omnivory $\cdot$ Carbon $\cdot$ Nitrogen $\cdot$ Phosphorus Resale or republication not permitted without written consent of the publisher

\section{INTRODUCTION}

Consumption of different food resources by zooplankton not only affects their growth and reproduction, but also helps structure planktonic communities and potentially controls biogeochemical cycling of various elements. It is well known now that many planktonic crustacean species are not limited to herbivory and will also consume other zooplankton or detritus (reviewed in Steinberg \& Saba 2008). Mesozooplankton typically has higher clearance rates for heterotrophic protozoans than for phytoplankton (Stoecker \& Capuzzo 1990, Fessenden \& Cowles 1994, Merrell \& Stoecker 1998, Broglio et al. 2004). For example, the copepod Acartia tonsa was found to derive 3 to $52 \%$ of its daily ration from predation on ciliates and dinoflagellates $>10 \mu \mathrm{m}$ in a subtropical estuary (Gifford \& Dagg 1988, Stoecker \& Capuzzo 1990), and some copepods feed solely on microzooplankton during periods of relatively low phytoplankton biomass (Fessenden \& Cowles 1994). Protozoan diets may enhance growth and survival of predators and also increase egg production, most likely due to their typically lower carbon:nitrogen $(\mathrm{C}: \mathrm{N})$ ratios and higher levels of essential nutrients, such as polyunsaturated fatty acids (PUFAs including eicosapentaenoic acid [EPA] and docosahexaenoic acid [DHA]), sterols, and amino acids, compared to phytoplankton (Stoecker \& Egloff 1987, Stoecker \& Capuzzo 1990, Gifford 1991). Some microzooplankton species such as the heterotrophic dinofla- 
gellates Oxyrrhis marina and Gyrodinium dominans, are important for trophic upgrading, possessing the ability to synthesize EPA, DHA, and sterols from lowquality algae and, thus, enhancing the transfer of essential nutrients through the microbial food web from phytoplankton to mesozooplankton (Klein Breteler et al. 1999, Tang \& Taal 2005). While we now know the importance of protozoans in copepod diets, little is known about how carnivorous or omnivorous diets affect metabolic processes, including the release of dissolved inorganic nutrients and dissolved organic matter (DOM) that support phytoplankton and bacterial growth and fuel the microbial loop.

Mesozooplankton contribute to nutrient release via sloppy feeding (the physical breaking of the food source), excretion, egestion, and subsequent fecal pellet leaching (Møller 2007). In our study we did not differentiate between these modes of nutrient production; thus, our reported copepod 'release rates' incorporate nutrient production from all of these modes. While crustacean zooplankton species are considered to be primarily ammonotelic, releasing ammonium $\left(\mathrm{NH}_{4}{ }^{+}\right)$as a metabolic byproduct (Bidigare 1983), organic $\mathrm{N}$ can also be a significant proportion of the total $\mathrm{N}$ released by zooplankton. For example, organic $\mathrm{N}$ excretion (urea and dissolved primary amines, DPA) by Acartia tonsa copepods was between 62 and $89 \%$ of total N excreted in mesocosm experiments (Miller \& Glibert 1998). Additionally, the rate of DOM release by zooplankton likely exceeds that directly released by phytoplankton (Jumars et al. 1989). Strom et al. (1997) found that zooplankton grazers released 16 to $37 \%$ of an algal cell's total $\mathrm{C}$ content as dissolved organic carbon (DOC) compared to only 3 to $7 \%$ DOC released as direct exudation from algal cells. Studies measuring phosphorus (P) release by zooplankton are scarce and few report dissolved organic phosphorus (DOP) release, which can be readily available to phytoplankton and bacteria (Hargrave \& Geen 1968, Titelman et al. 2008). A recent study demonstrated the importance of copepod feeding activity on the release of bioavailable DOP (as deoxyribonucleic acid, DNA) (Titelman et al. 2008). In another study, up to $74 \%$ of total $P$ released was DOP (as opposed to inorganic phosphate, $\mathrm{PO}_{4}{ }^{3-}$ ) and was readily available to bacteria (Hargrave \& Geen 1968).

Nutrient release rates, and the chemical composition of the nutrients produced, may be affected by a number of factors. In many studies, higher ingestion rates are correlated with higher zooplankton excretion rates (Corner et al. 1976, Kiørboe et al. 1985). Additionally, copepods have variable functional responses to different food items (Besiktepe \& Dam 2002, Mitra \& Flynn 2007), potentially causing differential release of byproducts. Zooplankton elemental composition regu- lates the elemental ratio of nutrients released; thus, a change in the zooplankton taxa or food source may cause a change in the excreted nutrient quantity and composition (Caron \& Goldman 1990, Gismervik 1997a, Strom et al. 1997, Elser \& Urabe 1999). For example, a consumer with low $\mathrm{N}$ and high $\mathrm{P}$ body content feeding on food with high $\mathrm{N}$ and low $\mathrm{P}$ content will retain the necessary $\mathrm{P}$ and excrete more N. Conversely, a consumer feeding on $\mathrm{N}$-limited food would retain the needed N and excrete more P (Sterner 1990, Touratier et al. 2001). Additionally, the composition of $\mathrm{N}$ and $\mathrm{P}$ released can be indirectly affected by feeding strategy. For example, Corner et al. (1976) showed that $\mathrm{NH}_{4}{ }^{+}$ was a higher portion of the total $\mathrm{N}$ released while copepods were feeding carnivorously. In contrast, Bidigare (1983) suggested that herbivores may be expected to excrete more urea than carnivores, as the conservation of arginine (a precursor of urea) is higher in marine phytoplankton than in zooplankton. However, this has not been supported by laboratory experiments, as Acartia tonsa urea excretion rates were higher when feeding on ciliates compared to diatoms, and these excretion rates increased with decreasing food C:N (Miller \& Roman 2008).

Nearly all copepod feeding experiments that measure nutrient excretion have been conducted with phytoplankton as food. Only 2 studies (Strom et al. 1997, Miller \& Roman 2008) have investigated DOM release by copepods feeding on microzooplankton. Strom et al. (1997) measured DOC production, and Miller \& Roman (2008) measured the forms of N released. With the exception of 1 study using the freshwater grazer Daphnia (Frost et al. 2004), no studies have measured simultaneous $\mathrm{C}, \mathrm{N}$, and P release from marine zooplankton, nor how release of dissolved organic (DOC, DON, DOP) and inorganic nutrients are related. Additionally, no previous nutrient-release studies have included an omnivorous diet, the feeding strategy of most copepods. Thus, we know little about the effects of microzooplankton or mixed diets on the stoichiometry of regenerated nutrient pools. In the present study, we determined the effects of herbivorous, omnivorous, and carnivorous feeding by Acartia tonsa copepods on the release rate of dissolved organic $\mathrm{C}, \mathrm{N}$, and $\mathrm{P}$ and inorganic nutrients, ammonium and phosphate. We also explored the stoichiometry of excretion, as well as the composition of the excreted $\mathrm{N}$ and $\mathrm{P}$.

Understanding the role of zooplankton nutrition on the conditions and magnitude of DOM release is pertinent, because changes in the sources and sinks of marine DOM may significantly influence other nutrient pools. Additionally, determining the stoichiometry of released $\mathrm{C}, \mathrm{N}$, and $\mathrm{P}$ is vital to understand how these pools are coupled. 


\section{MATERIALS AND METHODS}

Collection and culture of organisms. Acartia tonsa, a common coastal omnivorous calanoid copepod, were collected from the York River, USA, a tributary of Chesapeake Bay, by near-surface net tows $(0.5 \mathrm{~m}$ diameter net, $200 \mu \mathrm{m}$ mesh, non-filtering cod end). Copepods for the 2 experiments were collected $5 \mathrm{~d}$ apart, but from the same location and during the same tidal cycle. Upon collection, healthy, active A. tonsa were placed in $0.2 \mu \mathrm{m}$ filtered seawater for 1 to $2 \mathrm{~h}$ until the start of the acclimation period (see below). The mean size of adult $A$. tonsa was determined from 50 randomly selected individuals from the tow for which we measured cephalothorax width and total body length (from the top of the head to the base of the caudal rami) under an Olympus SZX12 dissecting scope at $230 \times$ magnification.

Two common estuarine heterotrophic dinoflagellates were used as prey items for Acartia tonsa: Oxyrrhis marina and Gyrodinium dominans (both isolated from Narragansett Bay). Both microzooplankton species are readily ingested by $A$. tonsa copepods (Tang \& Taal 2005). Dinoflagellate cultures were maintained in $f / 2$ medium ( $20 \%$ salinity) prepared with the $0.2 \mu \mathrm{m}$ filtered seawater (FSW) used in the experiment. The FSW consisted of a 1:1 ratio of deep Santa Barbara Channel seawater (SBSW) to artificial seawater (ASW) made with sodium chloride combusted at $500^{\circ} \mathrm{C}$ for $2 \mathrm{~h}$ to remove organics. ASW was used in order to start the experiments with a low background of DOM (Protocols for the Joint Global Ocean Flux Study [JGOFS] Core Measurements 1994), and it was combined with low DOM, deep SBSW, to prevent the copepods in the experiments from becoming lethargic, as has been noted for $100 \%$ ASW (Strom et al. 1997). The final seawater mixture had DOC and total dissolved nitrogen (TDN) concentrations of 23 and $2 \mu \mathrm{mol} \mathrm{l}^{-1}$, respectively. The cultures were incubated at $20^{\circ} \mathrm{C}$ in the dark. Both $O$. marina and G. dominans were maintained on a diet of the chlorophyte Dunaliella tertiolecta (CCMP 1320). The experiments were conducted once the dinoflagellate cultures reached the early stationary phase, when protozoan cell abundance was maximum and algal food was minimum (Tang \& Taal 2005). The diatom prey Thalassiosira weissflogii (CCMP 1336), was chosen as the food alga in our experiments due to its similar size to $O$. marina and G. dominans. These cultures were grown on $f / 2+$ Si medium made with $20 \%$ FSW, incubated at $20^{\circ} \mathrm{C}$ on a $12 \mathrm{~h}$ light: $12 \mathrm{~h}$ dark regime, and maintained in exponential phase by diluting with medium every 3 to $4 \mathrm{~d}$. The length and width of the food items were measured after the experiment on a Nikon DIAPHOT-TMD inverted microscope at $600 \times$ magnification (fixed in $2 \%$ Lugol's solution). Cell vol- umes were calculated according to geometric cell shapes ( $T$. weissflogii, cylinder; heterotrophic dinoflagellates, prolate ellipsoid). Cell volumes were corrected for fixative shrinkage after Montagnes et al. (1994) for diatoms and using athecate dinoflagellate shrinkage estimates for $O$. marina and $G$. dominans from Menden-Deuer et al. (2001).

Experimental procedure. To examine the impact of diet on Acartia tonsa ingestion and nutrient release, 3 food categories were used: (1) exclusively microzooplankton/carnivorous diet ( $\mu \mathrm{Z})$, (2) exclusively diatom/ herbivorous diet (DIATOM), and (3) mixed omnivorous diet (MIX) in which microzooplankton and diatoms each contributed $50 \%$ to the food carbon. Food C contents were estimated from volume measurements made prior to the start of the experiments using cell $\mathrm{C}$ to volume conversions from Menden-Deuer \& Lessard (2000) for heterotrophic dinoflagellates Oxyrrhis marina and Gyrodinium dominans and from Dam \& Lopes (2003) for Thalassiosira weissflogii diatoms. Two experiments were conducted using heterotrophic dinoflagellates as microzooplankton prey items, Expt A (O. marina) and Expt B (G. dominans). Both experiments used the diatom $T$. weissflogii.

Twenty-four hours prior to experimental incubations, freshly collected adult copepods were individually transferred from beakers into 3 separate $3.5 \mathrm{l}$ bottles, each with FSW and the appropriate food items for the $\mu \mathrm{Z}$, DIATOM, and MIX food categories, to a final concentration of 60 copepods $1^{-1}$, which is near the maximum concentration that occurs in Chesapeake Bay (CBP 2000) and the lowest concentration for which we could detect nutrient release in preliminary trials with varying copepod densities and incubation times. Food items were standardized to $300 \mu \mathrm{g} \mathrm{Cl}^{-1}$, a food density at which Acartia tonsa shows maximum ingestion rates on Thalassiosira weissflogii and Oxyrrhis marina (Besiktepe \& Dam 2002), using the size to C conversion factors noted above. Food $\mathrm{C}$ was never depleted to $<30 \%$ of the initial food concentration in any of the experiments. All bottles were topped off with FSW, covered with parafilm to remove bubbles, capped, and placed on a rotating wheel in the dark at $1 \mathrm{rpm}$ for $24 \mathrm{~h}$, similar to acclimation times used in other copepod feeding studies (Merrell \& Stoecker 1998, Tang et al. 2001).

At the end of the food acclimation period for each experiment, 12 incubation bottles $(300 \mathrm{ml})$ each were used for the carnivorous, herbivorous, and mixed diet. Each set included 6 controls (FSW + food) and 6 treatments (FSW + food + copepod predators). All bottles were set up in the same way as the acclimation bottles. For each of the sets, 3 controls and 3 treatments were set aside for initial sample collection. Remaining bottles were incubated as in the acclimation period. 
A suite of samples were taken initially and at the end of the $24 \mathrm{~h}$ incubation.

Sample analyses. Bacterial nutrient uptake: Because bacteria can utilize both DOM and inorganic nutrients, we accounted for their potential uptake during experimental incubations in our copepod release rate calculations. Samples for bacterial enumeration were fixed with formaldehyde (final conc. $2 \%$ ), stained with 4',6-diamidino-2-phenylindole (DAPI; final conc. $0.005 \%$ ), filtered onto $0.2 \mu \mathrm{m}$ black polycarbonate filters with $0.45 \mu \mathrm{m}$ cellulose backing filters, and slide mounted according to Sherr et al. (1983). For each sample, cells in 10 viewing fields were counted on a Nikon Eclipse 80i epifluorescent microscope at $1000 \times$ magnification. Using bacterial abundance data, we calculated an average concentration of bacteria, [C], as defined by Frost (1972). Separate samples were taken for bacterial production measurements using the $\left[{ }^{3} \mathrm{H}\right]$-leucine uptake method (Azam et al. 1983, Kirchman \& Ducklow 1993). Assuming a bacterial growth efficiency (BGE) of $50 \%$ (Azam et al. 1983), the bacterial $C$ demand (BCD, ng $\mathrm{C}^{-1} \mathrm{~h}^{-1}$ ) was estimated for each incubation bottle using Eq. (1a). We calculated potential daily bacterial DOC uptake $\left(U\right.$, ng $\left.\mathrm{C}^{-1} \mathrm{~d}^{-1}\right)$ during the grazing experiments using Eq. (1b), such that:

$$
\begin{aligned}
\mathrm{BCD} & =\frac{\mathrm{BP} \times 3.1}{\mathrm{BGE}} \\
U & =\mathrm{BCD} \times T
\end{aligned}
$$

where BP is bacterial production (pmol leucine $\mathrm{l}^{-1} \mathrm{~h}^{-1}$ ), 3.1 is the conversion from picomoles of leucine to nanograms of $\mathrm{C}$, and $T$ is incubation time $\left(24 \mathrm{~h} \mathrm{~d}^{-1}\right)$.

Additionally, using conservative estimates of bacterial molar C:N (4.5; Goldman \& Dennett 1991) and C:P (50; Kirchman 2000), we estimated maximum potential $\mathrm{N}$ and $\mathrm{P}$ uptake, respectively. Because bacteria can utilize both organic and inorganic N, we assumed $16 \%$ of the $\mathrm{N}$ uptake source was organic urea (calculated from Table 1 in Andersson et al. 2006) and $84 \%$ was inorganic $\mathrm{NH}_{4}{ }^{+}$. Bacteria can utilize DOP under certain conditions (Titelman et al. 2008); however, inorganic $\mathrm{PO}_{4}{ }^{3-}$ is their preferred $\mathrm{P}$ substrate (Cotner \& Wetzel 1992, Kirchman 2000). Because $\mathrm{PO}_{4}{ }^{3-}$ was available in our incubation bottles, we assumed $100 \%$ of the $\mathrm{P}$ source was inorganic and did not correct DOP release for bacterial uptake.

Feeding rates: Whole-water samples for algal and protozoan cell counts were preserved with acid Lugol's solution (final conc. 2\%). Subsamples for algal cell counts were settled in $1 \mathrm{ml}$ Sedgewick rafters, and 5 replicate frames each of at least 100 cells were counted with a Nikon DIAPHOT-TMD inverted microscope at $600 \times$ magnification. Subsamples (2 to $5 \mathrm{ml}$ ) for protozoans were settled in $5 \mathrm{ml}$ Utermöhl settling chambers, and entire contents (100 cells or more) were counted under an inverted microscope after at least a $24 \mathrm{~h}$ settling period (Utermöhl 1931, Hasle 1978). Clearance and ingestion rates of Acartia tonsa on both algae and microzooplankton were calculated according to Frost (1972). The possible ingestion of diatoms by the heterotrophic dinoflagellates in the MIX treatment was examined by monitoring the abundance of diatoms over the incubation time in the control bottles. Thalassiosira weissflogii concentration in the MIX controls remained constant over the incubation, similar to $T$. weissflogii in the DIATOM controls. This suggests no significant grazing occurred by heterotrophic dinoflagellates in the MIX treatments.

Nutrient analyses: After bacterial production and all abundance samples were collected, the remaining volume from each bottle was prescreened through a $200 \mu \mathrm{m}$ sieve (to retain copepods in treatments; controls were treated the same) directly into 2 filter towers and filtered through combusted GF/F filters into acid-cleaned, combusted flasks. One GF/F filter was collected for fluorometric chlorophyll analysis (Parsons et al. 1984). The second filter was collected for particulate carbon (PC) and particulate nitrogen (PN) (carbon-hydrogen-nitrogen elemental analyzer, EA1108). The collected copepods, which were all alive and active after incubation, were filtered onto a combusted GF/F, counted under a dissecting scope (Olympus SZX12), and analyzed for PC and PN content. The remaining filtrate for each replicate was analyzed for organic and inorganic nutrient concentrations: DOC, Shimadzu TOC analyzer 5000A (minimum detection limit $[\mathrm{MDL}]=0.5$ to $1.0 \mu \mathrm{mol} \mathrm{l}^{-1}$ ) after acidification and purging of dissolved inorganic carbon (Peltzer et al. 1996); ammonium, phenol/ hypochlorite Koroleff method with $\mathrm{MDL}=0.05 \mu \mathrm{mol}$ $\mathrm{l}^{-1}$ (Grasshoff et al. 1983); urea, diacetyl monoxime procedure with MDL $=0.05 \mu \mathrm{mol} \mathrm{l} \mathrm{l}^{-1}$ (adapted from Price \& Harrison 1987); DPAs, fluorescent O-phthaldealdehyde (OPA) method with $\mathrm{MDL}=0.05 \mu \mathrm{mol} \mathrm{l}^{-1}$ (Parsons et al. 1984); nitrate and nitrite (NOx; Grasshoff method), phosphate $\left(\mathrm{PO}_{4}{ }^{3-} ;\right.$ Koroleff method) $\left(\mathrm{MDL}=0.05 \mu \mathrm{mol} \mathrm{l^{-1 }}\right.$ ), and TDN and TDP (persulfate oxidation; $\mathrm{MDL}=1.0 \mu \mathrm{mol} \mathrm{l}^{-1}$ ), were determined with a QuikChem 8500 AutoAnalyzer (Grasshoff et al. 1983, Bronk et al. 2000, Sharp 2002). Concentrations of bulk DON and DOP were calculated by the difference between TDN and inorganic $\mathrm{N}\left(\mathrm{NO} x+\mathrm{NH}_{4}{ }^{+}\right)$ and TDP and $\mathrm{PO}_{4}{ }^{3-}$, respectively. Copepod release rates (in ng ind. ${ }^{-1} \mathrm{~h}^{-1}$ ) were calculated according to Miller \& Glibert (1998), but modified to include bacterial uptake, such that:

$$
\frac{\left[\left(\Delta C_{t}+U_{t}\right)-\left(\Delta C_{c}+U_{c}\right)\right] \times \mathrm{V}}{(\mathrm{N} \times \mathrm{T})}
$$


where $\Delta C_{\mathrm{t}}$ is the change in nutrient concentrations (ng $\mathrm{l}^{-1} \mathrm{~d}^{-1}$ ) in the treatment bottles and $\Delta C_{\mathrm{c}}$ is the average change in nutrient concentrations $\left(\mathrm{ng} \mathrm{l}^{-1} \mathrm{~d}^{-1}\right)$ in the control bottles; $U_{\mathrm{t}}$ and $U_{\mathrm{c}}$ are estimated values of bacterial uptake (ng $\mathrm{l}^{-1} \mathrm{~d}^{-1}$ ) in the treatment and control bottles (see Eq. 1b); $V$ is the incubation volume (l), $N$ is the number of copepods in the treatment bottles, and $T$ is incubation time $\left(24 \mathrm{~h} \mathrm{~d}^{-1}\right)$.

Statistical analysis. Statistical comparisons of the effects of diet on ingestion rates, release rates, and stoichiometry were made by 1-way ANOVA, employing the $\mathrm{p}=0.05$ level of significance.

\section{RESULTS}

\section{Predator size and $\mathrm{C}$ and $\mathbf{N}$ content}

Acartia tonsa copepods collected for Expts A and B were of similar sizes and had similar $C: N$ ratios. The total body length of adult $A$. tonsa showed a normal size distribution, with mean values of $1085 \mu \mathrm{m}$ for Expt A and $1121 \mu \mathrm{m}$ for Expt B, and coefficients of variance $(\mathrm{CV})$ of 6.47 and $5.84 \%$, respectively (Table 1 ). Copepod $\mathrm{C}$ and $\mathrm{N}$ contents ranged from 2.1 to $3.7 \mu \mathrm{g} \mathrm{C}$ and 0.5 to $0.9 \mu \mathrm{g} \mathrm{N}$, respectively, yielding $\mathrm{C}: \mathrm{N}$ ratios between 3.7 and $4.1 \mathrm{~g} \mathrm{~g}^{-1}$. The averages are reported in Table 1.

Table 1. Acartia tonsa. Size (length and equivalent spherical diameter, ESD) carbon (C) and nitrogen $(\mathrm{N})$ contents of the calanoid copepod predator A. tonsa for Expts A and B. Values are mean \pm SD with $n=30$ (length and ESD) and $n=5$ to 8 ( $\mathrm{C}$ and $\mathrm{N}$ contents) for each experiment

\begin{tabular}{|cccccc|}
\hline Expt & $\begin{array}{c}\text { Length } \\
(\mu \mathrm{m})\end{array}$ & $\begin{array}{c}\text { ESD } \\
(\mu \mathrm{m})\end{array}$ & $\begin{array}{c}\mathrm{C} \\
\left(\mu \mathrm{g} \mathrm{copepod}^{-1}\right)\end{array}$ & $\begin{array}{c}\mathrm{C}: \mathrm{N} \\
\left(\mathrm{g} \mathrm{g}^{-1}\right)\end{array}$ \\
\hline $\mathrm{A}$ & $1085 \pm 70$ & $418 \pm 59$ & $3.1 \pm 0.3$ & $0.8 \pm 0.1$ & $3.9 \pm 0.2$ \\
$\mathrm{~B}$ & $1121 \pm 65$ & $446 \pm 51$ & $2.6 \pm 0.1$ & $0.7 \pm 0.1$ & $4.0 \pm 0.1$ \\
\hline
\end{tabular}

\section{Food size, $\mathrm{C}$ and $\mathrm{N}$ content, and initial concentration}

The cell volumes of food items Thalassiosira weissflogii, Oxyrrhis marina, and Gyrodinium dominans ranged from 673 to 2875,1016 to 2228 , and 520 to $2228 \mathrm{\mu m}^{3}$, respectively (averages reported in Table 2), and the CV ranged from 33 to $38 \%$. Equivalent spherical diameter (ESD) was highest in $O$. marina and lowest in G. dominans (Table 2), with a combined average $\mathrm{CV}$ of $11.4 \%$. Despite being the smallest food item, the heterotrophic dinoflagellate $G$. dominans had the highest cellular $\mathrm{C}$ and $\mathrm{N}$ content. Cellular $\mathrm{C}$ contents of all food items were lower than the estimates derived from Menden-Deuer \& Lessard (2000) and Dam \& Lopes (2003), which we used to standardize the $C$ in the experimental bottles. Thus, initial food concentrations were about half the targeted $300 \mu \mathrm{g} \mathrm{C} \mathrm{l}^{-1}$ (Table 3). However, these food concentrations do not fall below threshold feeding levels and are at the near-saturating levels determined for Acartia tonsa by Besiktepe \& Dam (2002). In Expt A, the DIATOM treatment had significantly higher initial food $\mathrm{C}$ concentration compared to the MIX treatment $(\mathrm{p}<0.01)$. All other initial food concentrations were similar between treatments. Initial C concentration of $G$. dominans in the $\mu \mathrm{Z}$ treatment (Expt B) was significantly higher than $C$ concentrations in the DIATOM (Expt B) and MIX treatment ( $p<0.01)$.

\section{Feeding rates}

Ingestion rates of copepods feeding on the $\mu \mathrm{Z}$, DIATOM, and MIX diets in Expt A (Oxyrrhis marina as the microzooplankton food source, Thalassiosira weissflogii as the algal food source) were not statistically different from each other and averaged 1.25, 1.58, and $1.13 \mu \mathrm{g} \mathrm{C}$ ind. ${ }^{-1} \mathrm{~d}^{-1}$ or 42,53 , and $38 \%$ of copepod body $\mathrm{C} \mathrm{d}^{-1}$, respectively (Fig. 1a). Ingestion rates for all treatments in Expt B (Gyrodinium dominans as the microzooplankton food source, T. weissflogii as the

Table 2. Thalassiosira weissflogii, Oxyrrhis marina, Gyrodinium dominans. Food size (length, width, volume, and equivalent spherical diameter, ESD), carbon $(\mathrm{C})$ and nitrogen $(\mathrm{N})$ contents. Values are mean \pm SD with $\mathrm{n}=50$ (size parameters) and $\mathrm{n}=6$ (C and $\mathrm{N}$ content) for each experiment. Food size and $\mathrm{C}$ and $\mathrm{N}$ contents were measured at the start of the experiments, cell volumes were corrected for Lugol-derived shrinkage (see 'Materials and methods')

\begin{tabular}{|c|c|c|c|c|c|c|c|}
\hline Food & $\begin{array}{l}\text { Length } \\
(\mu \mathrm{m})\end{array}$ & $\begin{array}{l}\text { Width } \\
(\mu \mathrm{m})\end{array}$ & $\begin{array}{c}\text { Volume } \\
\left(\mu \mathrm{m}^{3}\right)\end{array}$ & $\begin{array}{l}\text { ESD } \\
(\mu \mathrm{m})\end{array}$ & $\begin{array}{c}\mathrm{C} \\
\left(\mathrm{pg} \mathrm{cell}^{-1}\right)\end{array}$ & $\begin{array}{c}\mathrm{N} \\
\left(\text { pg cell }^{-1}\right)\end{array}$ & $\begin{array}{c}\text { C:N } \\
\left(\mathrm{g} \mathrm{g}^{-1}\right)\end{array}$ \\
\hline \multicolumn{8}{|l|}{ Expt A } \\
\hline T. weissflogii & $12 \pm 2.2$ & $9.1 \pm 1.4$ & $1511 \pm 577$ & $14 \pm 1.7$ & $53 \pm 6.6$ & $10 \pm 1.9$ & $5.6 \pm 0.6$ \\
\hline O. marina & $23 \pm 2.4$ & $12 \pm 1.5$ & $1802 \pm 624$ & $15 \pm 1.6$ & $268 \pm 63$ & $52 \pm 7.6$ & $5.1 \pm 0.9$ \\
\hline \multicolumn{8}{|l|}{ Expt B } \\
\hline T. weissflogii & $12 \pm 2.0$ & $8.8 \pm 1.1$ & $1396 \pm 463$ & $14 \pm 1.5$ & $73 \pm 10$ & $13 \pm 2.0$ & $5.5 \pm 0.3$ \\
\hline G. dominans & $20 \pm 2.0$ & $10 \pm 1.5$ & $1209 \pm 420$ & $13 \pm 1.5$ & $329 \pm 54$ & $65 \pm 9.2$ & $5.1 \pm 0.3$ \\
\hline
\end{tabular}


Table 3. Oxyrrhis marina, Thalassiosira weissflogii, Gyrodinium dominans. Average initial food conditions. Values are mean $\pm \mathrm{SD}, \mathrm{n}=3$ for each treatment

\begin{tabular}{|lc|}
\hline & $\begin{array}{c}\text { Initial food concentration } \\
\left(\mu \mathrm{g} \mathrm{C} 1^{-1}\right)\end{array}$ \\
\hline Expt A & \\
Oxyrrhis marina & $147 \pm 30$ \\
Thalassiosira weissflogii & $162 \pm 18$ \\
O. marina/T. weissflogii MIX & $63 \pm 15$ \\
O. marina & $58 \pm 5$ \\
T. weissflogii & $121 \pm 16$ \\
Total & \\
Expt B & $233 \pm 19$ \\
Gyrodinium dominans & $160 \pm 3$ \\
Thalassiosira weissflogii & $80 \pm 17$ \\
G. dominans/T. weissflogii MIX & $56 \pm 6$ \\
G. dominans & $136 \pm 18$ \\
T. weissflogii & \\
Total & \\
\hline
\end{tabular}
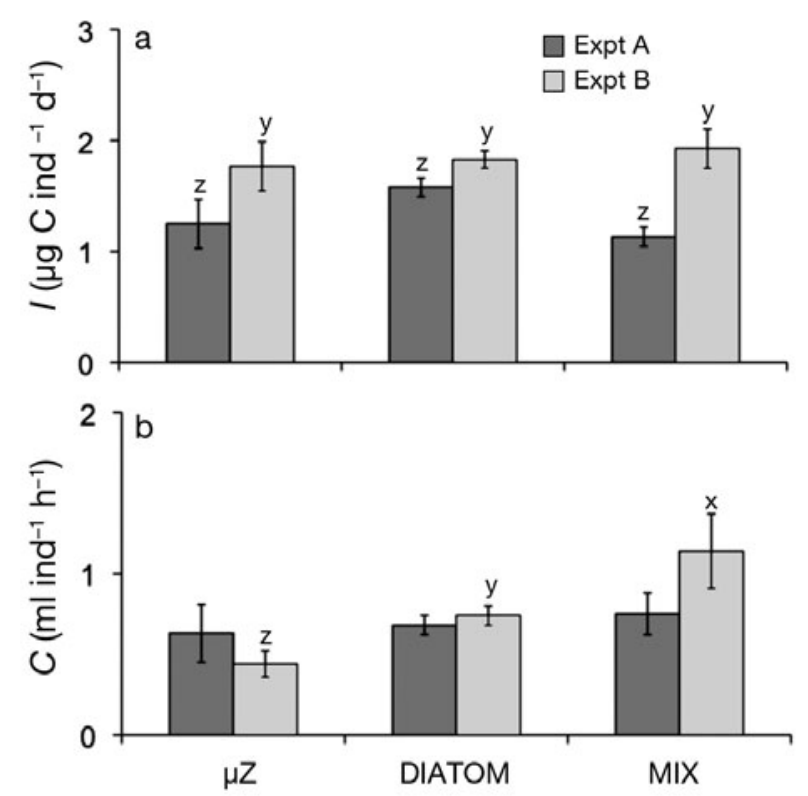

Fig. 1. Acartia tonsa. Feeding rates on a carnivorous microzooplankton diet $(\mu \mathrm{Z})$, a herbivorous diatom diet (DIATOM), and an omnivorous mixed diet (MIX) in Expts A and B. The $\mu \mathrm{Z}$ prey in Expt A was Oxyrrhis marina, and in Expt B was Gyrodinium dominans. The diatom food for both experiments was Thalassiosira weissflogii, and the mixed diet was a combination of the $\mu \mathrm{Z}$ and diatom food items. All values are mean $\pm \mathrm{SD}(\mathrm{n}=3)(\mathrm{a})$ Ingestion rate $(I)$; rates were converted from cells per individual per day using average measured C contents of food items shown in Table 2. Ingestion rates with different letters were significantly different from each other $(y>$ $z ; 1$-way ANOVA, $\mathrm{p}<0.05$ in $\mu \mathrm{Z}$ and DIATOM, $\mathrm{p}<0.01$ in MIX). (b) Clearance rates $(C)$ in $\mathrm{ml}$ per individual per hour; for the MIX treatments, rates for microzooplankton food and diatom food were calculated separately and then combined. Clearance rates with different letters were significantly different from each other $(x>y>z$; 1 -way ANOVA, $p<0.05)$ algal food source) were significantly higher than those in Expt $\mathrm{A}(\mathrm{p}<0.05$ in $\mu \mathrm{Z}$ and DIATOM; $\mathrm{p}<0.01$ in MIX), averaging $1.77,1.83$, and $1.93 \mu \mathrm{g} \mathrm{C}$ ind. ${ }^{-1} \mathrm{~d}^{-1}$ or 66,68 , and $72 \%$ of copepod body $\mathrm{C} \mathrm{d}^{-1}$, respectively. The ingestion rates for $\mu \mathrm{Z}$, DIATOM, and MIX in Expt B, however, were not significantly different from each other. In the MIX treatments, diatom $\mathrm{C}$ accounted for $52 \%$ of total $\mathrm{C}$ ingested in Expt $\mathrm{A}$ and $37 \%$ of total $\mathrm{C}$ ingested in Expt B. Clearance rates of copepods were similar between treatments in Expt A, with averages ranging from 0.63 to $0.75 \mathrm{ml}$ ind.$^{-1} \mathrm{~h}^{-1}$ (Fig. 1b). Clearance rates of copepods in Expt B, however, were significantly different between all treatments, being highest in the MIX treatment, lower in the DIATOM treatment, and lowest in the $\mu \mathrm{Z}$ treatment, and averaging $1.14,0.74$, and $0.44 \mathrm{ml}$ ind. ${ }^{-1} \mathrm{~h}^{-1}$, respectively (Fig. 1b).

\section{Bacterial nutrient uptake}

Estimated bacterial uptake of $\mathrm{C}, \mathrm{N}$, and $\mathrm{P}$ was minimal (1.4 to $27,0.4$ to 7.1 , and 0.1 to $1.4 \mathrm{ng} \mathrm{C}, \mathrm{N}$, and $\mathrm{P}$ $\mathrm{l}^{-1} \mathrm{~d}^{-1}$, respectively). Uptake was also similar between the controls and copepod treatments for each diet in both experiments (Table 4 ; $\mathrm{p}>0.05$ ). This is most likely due to the similar bacterial abundance, $[C]$, between the controls and copepod treatments (Table $4 ; \mathrm{p}>$ 0.05). Thus, there were no significant differences in uncorrected and uptake-corrected nutrient release rates $(p>0.05)$. To test this further, we recalculated bacterial uptake to increase the potential uptake of $\mathrm{C}$, $\mathrm{N}$, and $\mathrm{P}$ using more conservative conversion factors including $\mathrm{BGE}=10 \%$ (del Giorgio \& Cole 2000), C:N = 3.8 (Fukuda et al. 1998), and C:P = 8 (Bratbak 1985). These uptake-corrected release rates were not significantly different from the uncorrected release rates either $(\mathrm{p}>0.05)$.

\section{Copepod nutrient release}

DOC release rates in the $\mu \mathrm{Z}$ treatment for both experiments were significantly higher than the DOC produced by copepods feeding on an exclusively diatom or on a mixed diet (Fig. 2). DOC release in the MIX treatment was undetectable in Expt A and near zero in Expt B. Average release rates for the $\mu \mathrm{Z}$ and DIATOM treatments ranged from 34 to $83 \mathrm{ng} \mathrm{C}$ ind. ${ }^{-1}$ $\mathrm{h}^{-1}$ and 4 to $15 \mathrm{ng} \mathrm{C}$ ind. ${ }^{-1} \mathrm{~h}^{-1}$ and correspond to 67-116 and $6-20 \%$ of $\mathrm{C}$ ingested $\mathrm{d}^{-1}$, respectively. Additionally, DOC release rates were higher for copepods feeding on Gyrodinium dominans (Expt B) compared to Oxyrrhis marina (Expt A) in the $\mu \mathrm{Z}$ treatments $(\mathrm{p}<0.05)$. 
Table 4. Mean bacterial abundance, $[C]$, and mean estimated daily bacterial $\mathrm{C}, \mathrm{N}$, and $\mathrm{P}$ demands used for uptake corrections on release rates in Expts A and B. The $\mu \mathrm{Z}$ prey in Expt A was Oxyrrhis marina, and in Expt B was Gyrodinium dominans. The diatom food for both experiments was Thalassiosira weissflogii, and the mixed diet was a combination of the $\mu \mathrm{Z}$ and diatom food items. Nutrient demands (total $\mathrm{C}, \mathrm{N}$, and P) were calculated using ${ }^{3}[\mathrm{H}]$-leucine bacterial production data, a bacterial growth efficiency estimate of $50 \%$, and estimates of bacterial molar C:N (4.5) and C:P (50) (see 'Materials and methods' for details); $\mathrm{n}=3$ for $[C]$ and $\mathrm{C}, \mathrm{N}$, and $\mathrm{P}$ daily nutritional demands

\begin{tabular}{|lcccc|}
\hline & $\begin{array}{c}{[C]} \\
\left(\text { cells } \mathrm{ml}^{-1} \times 10^{5}\right)\end{array}$ & \multicolumn{4}{c|}{$\begin{array}{c}\text { Daily nutritional demand } \\
\left(\mathrm{ng} \mathrm{l}^{-1} \mathrm{~d}^{-1} \times 10^{-1}\right)\end{array}$} \\
& & $\mathrm{C}$ & $\mathrm{N}$ & $\mathrm{P}$ \\
\hline Expt A & & & & \\
$\mu Z$ Control & $1.8 \pm 0.1$ & $41 \pm 0.5$ & $11 \pm 0.1$ & $2.2 \pm 0.03$ \\
$\mu Z+$ Copepods & $2.3 \pm 0.2$ & $53 \pm 4.4$ & $14 \pm 1.1$ & $2.8 \pm 0.03$ \\
DIATOM Control & $0.7 \pm 0.1$ & $14 \pm 0.5$ & $3.8 \pm 0.1$ & $0.6 \pm 0.03$ \\
DIATOM + Copepods & $1.3 \pm 0.1$ & $28 \pm 2.8$ & $7.0 \pm 0.7$ & $1.5 \pm 0.15$ \\
MIX Control & $2.2 \pm 0.1$ & $48 \pm 1.2$ & $12 \pm 0.3$ & $2.5 \pm 0.06$ \\
MIX + Copepods & $1.9 \pm 0.1$ & $42 \pm 2.0$ & $11 \pm 0.6$ & $2.2 \pm 0.12$ \\
Expt B & & & & \\
$\mu Z$ Control & $11 \pm 0.1$ & $270 \pm 3.7$ & $70 \pm 1.0$ & $14 \pm 0.19$ \\
$\mu Z+$ Copepods & $10 \pm 0.4$ & $256 \pm 10$ & $66 \pm 2.7$ & $13 \pm 0.53$ \\
DIATOM Control & $5.6 \pm 0.5$ & $115 \pm 11$ & $29 \pm 2.8$ & $5.9 \pm 0.56$ \\
DIATOM + Copepods & $5.6 \pm 0.2$ & $116 \pm 4.9$ & $29 \pm 1.3$ & $5.9 \pm 0.25$ \\
MIX Control & $2.4 \pm 0.1$ & $55 \pm 1.2$ & $14 \pm 0.3$ & $2.8 \pm 0.06$ \\
MIX + Copepods & $3.2 \pm 0.3$ & $76 \pm 5.8$ & $20 \pm 1.5$ & $4.0 \pm 0.31$ \\
& & & & \\
\hline
\end{tabular}

on the order of 1 to $2 \mathrm{ng} \mathrm{P}$ ind..$^{-1} \mathrm{~h}^{-1}$ (Fig. $4 \mathrm{a}$ ), but did reach as high as $11.5 \mathrm{ng} \mathrm{P}$ ind. ${ }^{-1} \mathrm{~h}^{-1}$ (Fig. 4a). In Expt A, the average $\mathrm{PO}_{4}{ }^{3-}$ release rates were highest in the DIATOM treatment and lower in the $\mu \mathrm{Z}$ and MIX treatments $(\mathrm{p}<$ 0.05). The average $\mathrm{PO}_{4}{ }^{3-}$ release rates in Expt B were highest in the $\mu \mathrm{Z}$ treatment (average $=10.6 \mathrm{ng} \mathrm{P}$ ind..$^{-1} \mathrm{~h}^{-1}$ ), lower in the DIATOM treatment (average $=1.65 \mathrm{ng} \mathrm{P}$ ind. ${ }^{-1} \mathrm{~h}^{-1}$ ), and undetectable in the MIX treatment $(p<0.05)$. Similarly to DOC and $\mathrm{NH}_{4}{ }^{+}$, release rates for $\mathrm{PO}_{4}{ }^{3-}$ were higher for copepods feeding on Gyrodinium dominans (Expt B) compared to Oxyrrhis marina (Expt A) in the $\mu \mathrm{Z}$ treatments $(\mathrm{p}<0.01)$. When DOP release rates were detectable, they were higher than inorganic $\mathrm{P}$ release rates and contributed 54 to $100 \%$ of the total $\mathrm{P}$ released (Fig. 4b). The detectable DOP release only occurred in treatments that contained microzooplankton prey.

Stoichiometry of nutrients released from copepods was quite variable (Fig. 5). Molar DOC:urea release ratios were highest in the $\mu \mathrm{Z}$ treatment (averages ranging from 172 to 187), lower in the DIATOM treatment (averages ranging from 13 to 63), and, when data

Mean $\mathrm{NH}_{4}{ }^{+}$release rates for each treatment ranged from 1.4 to $17 \mathrm{ng} \mathrm{N}$ ind. ${ }^{-1} \mathrm{~h}^{-1}$ (Fig. 3a). Similarly to DOC, $\mathrm{NH}_{4}{ }^{+}$release rates were significantly higher in the $\mu \mathrm{Z}$ treatment and lowest in the MIX treatment for both Expts A and B (Fig. 3a; p < 0.05). Low release rates of DOC and $\mathrm{NH}_{4}{ }^{+}$in the MIX treatment were unexpected due to the combined diet as well as the similar ingestion rates in the MIX treatment compared to the other treatments. $\mathrm{NH}_{4}{ }^{+}$release rates in the $\mu \mathrm{Z}$ treatment were also higher in Expt B compared to Expt A ( $\mathrm{p}<0.01)$.

Bulk DON release rates (calculated by subtracting inorganic $\mathrm{N}$ sources, $\mathrm{NO}_{x}$ and $\mathrm{NH}_{4}{ }^{+}$, from TDN) were undetectable due to a high background of $\mathrm{NO}_{x}$ during our experiments (up to $80 \mu \mathrm{mol} \mathrm{l}^{-1}$ ). DPA release rates were also below the detection limit. Thus, the released organic $\mathrm{N}$ we report is urea. Contrary to the patterns observed in DOC and $\mathrm{NH}_{4}{ }^{+}$release rates, urea release rates were highest in the MIX treatment and lowest in the $\mu \mathrm{Z}$ treatments for both experiments and ranged from undetectable to $4.1 \mathrm{ng} \mathrm{N}$ ind..$^{-1} \mathrm{~h}^{-1}$, but these differences were not statistically significant (Fig. 3b). Urea was a higher portion of the total $\mathrm{N}$ released in the MIX treatment (reaching up to $59 \%$ ) compared to in the other treatments (Fig. 3c; p < 0.05, Expt B).

Release rates of $\mathrm{P}$ were considerably more variable across treatments compared to those of other nutrients measured (Fig. 4). Phosphate release rates were mostly were available (Expt B), lowest in the MIX treatment (9.0; Fig. 5a; p < 0.05). These release ratios were also well above the Redfield ratio for $\mathrm{C}: \mathrm{N}$ of 6.6 , with averages ranging from 9 to $187 \mathrm{~mol} \mathrm{~mol}^{-1}$. DOC:TDN and TDN:TDP release ratios, on the other hand, were all below the Redfield ratio of 6.6 and 16, respec-

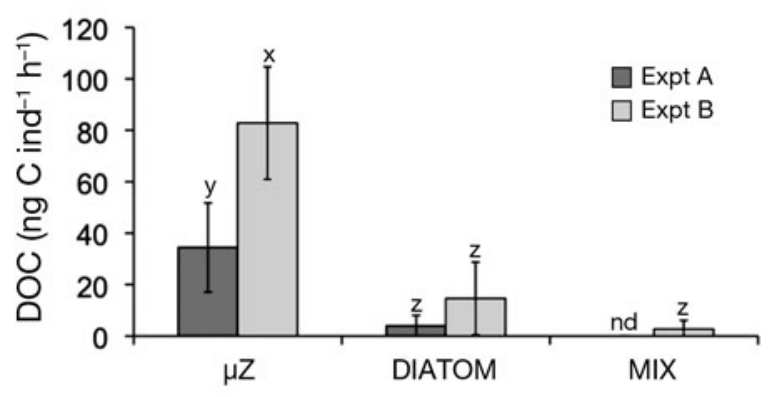

Fig. 2. Acartia tonsa. Dissolved organic carbon (DOC) release rates in nanograms $\mathrm{C}$ per individual per hour while feeding on a carnivorous microzooplankton diet $(\mu \mathrm{Z})$, a herbivorous diatom diet (DIATOM), and an omnivorous mixed diet (MIX) in Expts A and B. The $\mu \mathrm{Z}$ prey in Expt A was Oxyrrhis marina, and in Expt B was Gyrodinium dominans. The diatom food for both experiments was Thalassiosira weissflogii, and the mixed diet was a combination of the $\mu \mathrm{Z}$ and diatom food items. DOC release rates with different letters were significantly different from each other $(x>y>z$; 1 -way ANOVA, $\mathrm{p}<0.05)$. Values are mean $\pm \mathrm{SD}(\mathrm{n}=3)$. nd: DOC release not detected 

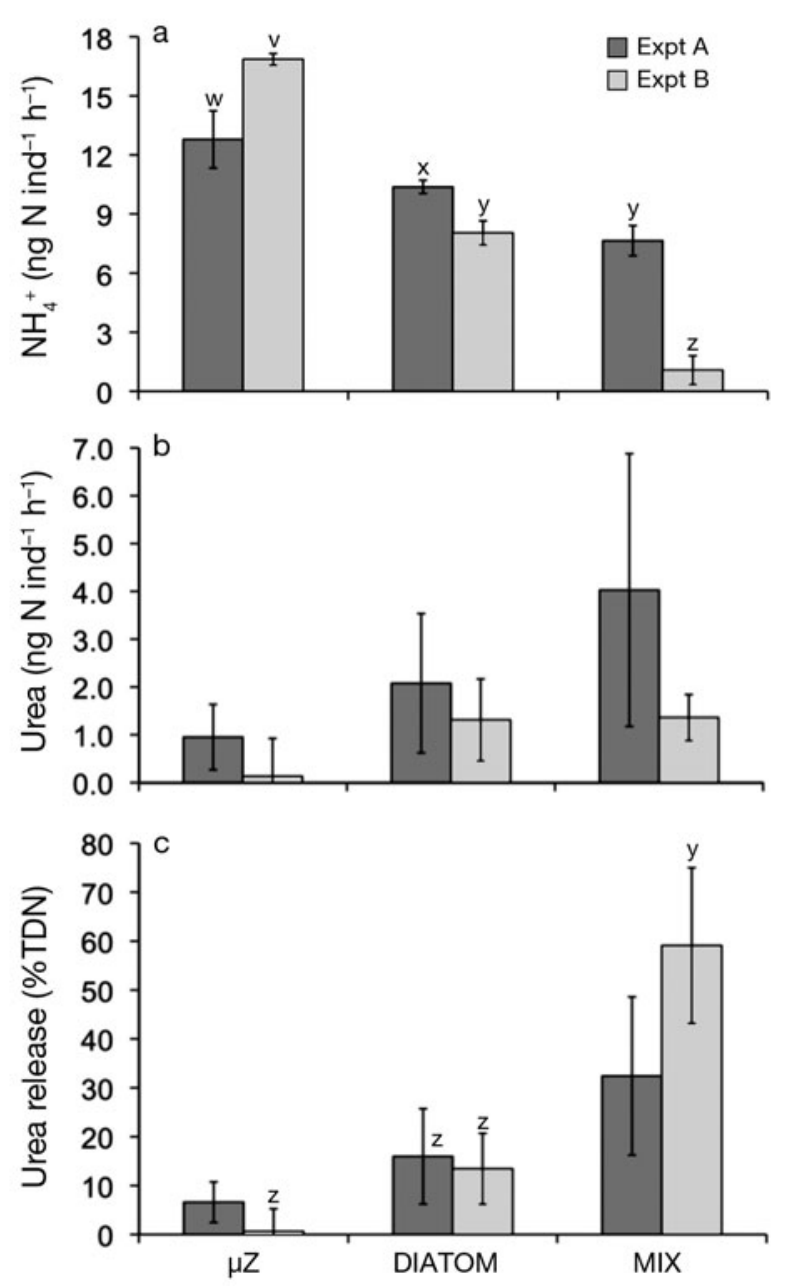

Fig. 3. Acartia tonsa. $\mathrm{N}$ release while feeding on a carnivorous microzooplankton diet $(\mu \mathrm{Z})$, a herbivorous diatom diet (DIATOM), and an omnivorous mixed diet (MIX) in Expts A and B. The $\mu \mathrm{Z}$ prey in Expt A was Oxyrrhis marina, and in Expt B was Gyrodinium dominans. The diatom food for both experiments was Thalassiosira weissflogii, and the mixed diet was a combination of the $\mu \mathrm{Z}$ and diatom food items. All values are mean $\pm \mathrm{SD}(\mathrm{n}=3)$. Release rates with different letters were significantly different from each other $(v>w>x>y>z$; 1 -way ANOVA, $\mathrm{p}<0.05)$. (a) Inorganic $\mathrm{N}\left(\mathrm{NH}_{4}{ }^{+}\right)$release rates in nanograms $\mathrm{N}$ per individual per hour. (b) Urea release rates in nanograms N per individual per hour. (c) Proportion of urea (organic $\mathrm{N}$ ) release as percentage of TDN (total dissolved nitrogen, $\mathrm{NH}_{4}{ }^{+}+$urea) release

tively. Released DOC:TDN ratios were highest in the $\mu \mathrm{Z}$ treatment (averages ranging from 3.0 to 5.7 ) and lower in the DIATOM (from 0.4 to 1.8 ) and MIX treatments (average for Expt $B=1.3$; Fig. 5b), but these differences were not significant. TDN:TDP release ratios, however, were highest in the DIATOM treatment (average $=12.5$ ) and lower in the treatments containing microzooplankton prey items (3.6 to 6.6 for $\mu \mathrm{Z}, 1.3$ to 8.3 for MIX; Fig. $5 c_{i}$ p $<0.01$ for Expt B).
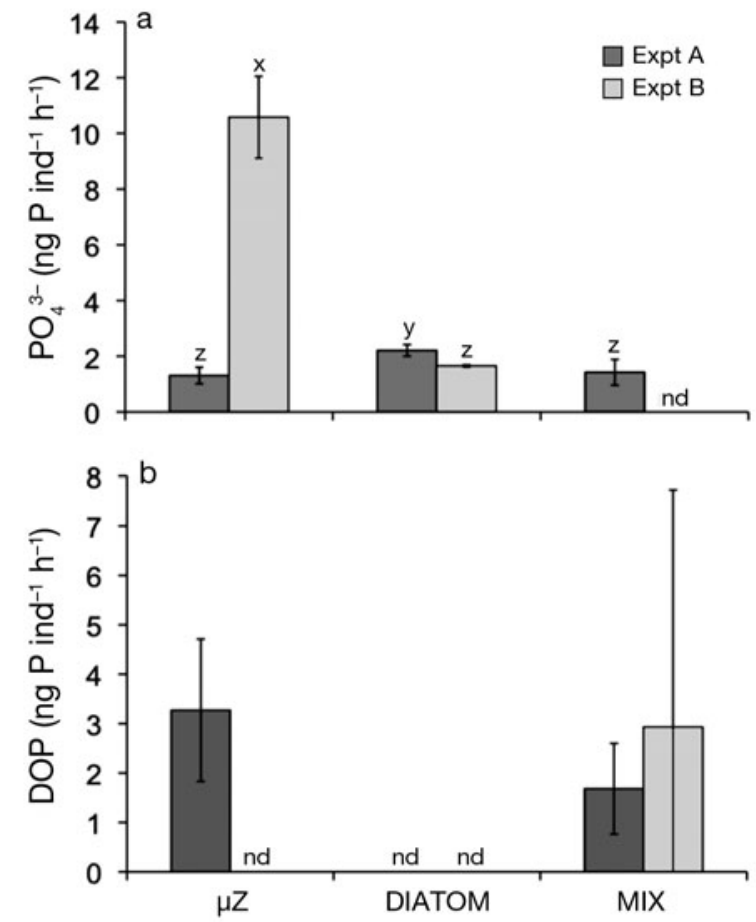

Fig. 4. Acartia tonsa. P release rates in nanograms $\mathrm{P}$ per individual per hour while feeding on a carnivorous microzooplankton diet $(\mu \mathrm{Z})$, a herbivorous diatom diet (DIATOM), and an omnivorous mixed diet (MIX) in Expts A and B. The $\mu \mathrm{Z}$ prey in Expt A was Oxyrrhis marina, and in Expt B was Gyrodinium dominans. The diatom food for both experiments was Thalassiosira weissflogii, and the mixed diet was a combination of the $\mu \mathrm{Z}$ and diatom food items. Values are mean $\pm \mathrm{SD}(\mathrm{n}=3)$. nd: $\mathrm{P}$ release not detected. (a) Inorganic $\mathrm{P}\left(\mathrm{PO}_{4}{ }^{3-}\right)$ release. Release rates with different letters were significantly different from each other $\left(x>y>z_{i}\right.$ 1-way ANOVA, $\left.\mathrm{p}<0.05\right)$. (b) Dissolved organic phosphate (DOP) release

\section{DISCUSSION}

Diet has been the focus of studies examining copepod feeding and reproduction (Stoecker \& Egloff 1987, Stoecker \& Capuzzo 1990, Kleppel \& Burkart 1995, Bonnet \& Carlotti 2001, Broglio et al. 2003). The central theme in these studies is the importance of protozoans in the copepod diet. The effect of a mixed diet (phytoplankton + protozoans), as opposed to mono-diets, on copepod metabolic processes has not been previously examined. Our study demonstrates for the first time that copepod diet affects relative organic and inorganic nutrient release rates as well as release stoichiometry.

\section{Feeding and nutrient release rates}

Average copepod C ingestion rates (1.13 to $1.58 \mu \mathrm{g} \mathrm{C}$ ind..$^{-1} \mathrm{~d}^{-1}$ ) were similar to those reported for Acartia 

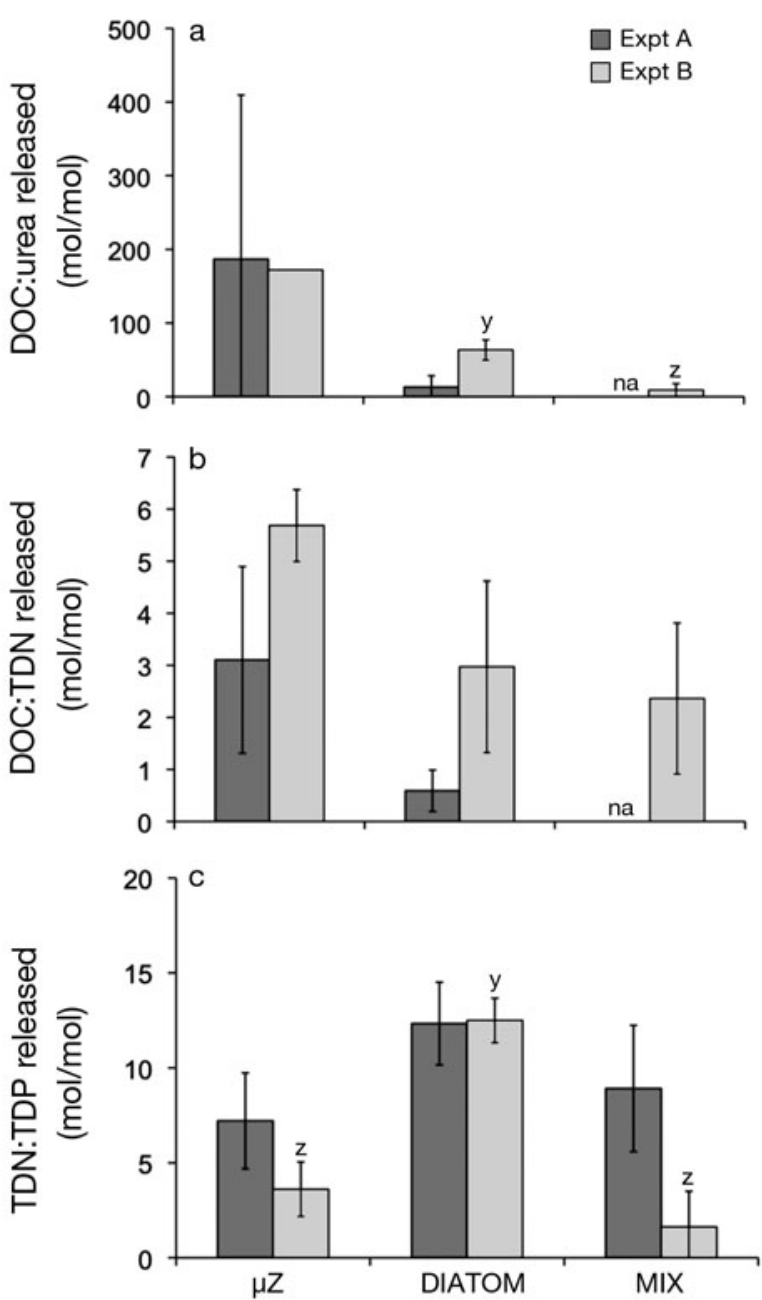

Fig. 5. Acartia tonsa. Stoichiometry of nutrient release while feeding on a carnivorous microzooplankton diet $(\mu \mathrm{Z})$, a herbivorous diatom diet (DIATOM), and an omnivorous mixed diet (MIX) in Expts A and B. The $\mu \mathrm{Z}$ prey in Expt A was Oxyrrhis marina, and in Expt B was Gyrodinium dominans. The diatom food for both experiments was Thalassiosira weissflogii, and the mixed diet was a combination of the $\mu \mathrm{Z}$ and diatom food items. All values are mean $\pm \mathrm{SD}(\mathrm{n}=3)$. Release ratios with different letters were significantly different from each other $(y>z ; 1$-way ANOVA, $p<0.05)$. na: data not available. (a) DOC:urea release, (b) DOC:TDN release, and (c) TDN:TDP release. Ratios calculated with TDN (total dissolved nitrogen) and TDP (total dissolved phosphate) represent combined dissolved inorganic + organic forms

tonsa in Miller \& Roman $\left(2008 ; 0.05\right.$ to $2.96 \mu \mathrm{g} \mathrm{C}$ ind. ${ }^{-1}$ $\mathrm{d}^{-1}$ ), but lower than those measured in Besiktepe \& Dam (2002; ca. 6 and $3.5 \mu \mathrm{g} \mathrm{C}$ ind..$^{-1} \mathrm{~d}^{-1}$ for copepods feeding on Thalassiosira weissflogii and Oxyrrhis marina, respectively, at food concentrations similar to those in our study).

Despite similar ingestion rates among treatments, as well as similar $\mathrm{C}: \mathrm{N}$ ratios of food items, Acartia tonsa release rates of DOC, urea, $\mathrm{DOP}, \mathrm{NH}_{4}{ }^{+}$, and $\mathrm{PO}_{4}{ }^{3-}$ were extremely variable between diet treatments. Because our release rates represent not only excretion, but also sloppy feeding and egestion/fecal pellet leaching, the hypothesis of ingestion-independent rates of excretion (Miller \& Landry 1984) can neither be supported nor rejected. A. tonsa DOC release rates (as percentage of food $C$ ingested) in our study are higher than those shown by Strom et al. (1997) for Calanus pacificus copepods feeding on Oxyrrhis marina (67 to $100 \%$ vs. ca. 16 to $28 \%$ ) and Thalassiosira weissflogii (5.8 to $20 \%$ vs. undetectable). Differences in the method, as well as conversion factors, used to correct for bacterial uptake could be one source of variation. While we measured bacterial production using the $\left[{ }^{3} \mathrm{H}\right]$-leucine uptake method, Strom et al. (1997) calculated potential bacterial DOC uptake using measured change in bacterial abundance, an estimated $40 \mathrm{fg} \mathrm{C}$ bacterial cell ${ }^{-1}$, and an estimated bacterial growth efficiency of $50 \%$. Using these conversions, bacteria utilized between 9 and $80 \%$ of the DOC produced according to Strom et al. (1997), while the proportion of DOC utilized by bacteria was negligible in our study.

Variation in DOC release rates between our study and that of Strom et al. (1997) are also likely due to the different sizes of copepods used for the experiments and the subsequent differences in DOC release by sloppy feeding. When copepod-to-prey ESD ratios are below the threshold of 55 as defined by Møller (2005), DOC release via sloppy feeding can occur. The copepod Calanus pacificus, used by Strom et al. (1997), is much larger $\left(E S D=1060 \mu m_{\text {; }}\right.$ Møller 2005) than Acartia tonsa $(\mathrm{ESD}=432 \mu \mathrm{m}$; present study). Thus, the calculated copepod-to-prey ESD ratios for C. pacificus feeding on the prey items Thalassiosira weissflogii, Oxyrrhis marina, and Gyrodinium dominans are always above the threshold for sloppy feeding (76.6, 71.2, and 81.5, respectively) compared to those calculated for A. tonsa (31.2, 29.0, and 33.2, respectively). Thus, sloppy feeding could be the source of the higher DOC release in our study compared to that by Strom et al. (1997). Using our copepod-to-prey ESD ratios in the equation of Møller (2005), we predicted the fraction of $\mathrm{C}$ removed from suspension and lost as DOC via sloppy feeding by A. tonsa feeding on $T$. weissflogii, $O$. marina, and G. dominans to be $30.8,33.7$, and $28.2 \%$, respectively. These estimates are even lower when we use the more conservative sloppy feeding DOC release equation of Møller (2007). The actual DOC release (as the fraction of $\mathrm{C}$ removed from suspension) measured in our study for $A$. tonsa grazing on $T$. weissflogii (8.7\% in Expt A, $29 \%$ in Expt B) was within the range of release predicted by Møller (2007); however, it is higher and above the ranges of sloppy feeding release predicted by Møller $(2005,2007)$ for O. marina $(67.1 \%$ ) and G. dominans (116\%). This suggests that excretion 
and, possibly, fecal pellet leaching were also important sources of DOC release in treatments with microzooplankton prey. However, no studies to date have attempted to separate the modes of DOC release (sloppy feeding vs. excretion vs. fecal pellet leaching), so the relative importance of each mode of release in the present study is not known.

Ammonium release rates (1.4 to $17 \mathrm{ng} \mathrm{N}$ ind. ${ }^{-1} \mathrm{~h}^{-1}$ ) were similar to those reported for Acartia tonsa by Miller \& Glibert (1998; undetectable to $28 \mathrm{ng} \mathrm{N}$ ind. ${ }^{-1}$ $\mathrm{h}^{-1}$ ) and Ikeda et al. (2001; $6.0 \mathrm{ng} \mathrm{N}$ ind. $\left.{ }^{-1} \mathrm{~h}^{-1}\right)$, but slightly higher than those reported by Miller \& Roman $\left(2008 ; 1.4\right.$ to $7.0 \mathrm{ng} \mathrm{N}$ ind. ${ }^{-1} \mathrm{~h}^{-1}$ ) for a range of food qualities. Additionally, DOC and $\mathrm{NH}_{4}^{+}$release rates were higher for copepods feeding on Gyrodinium dominans (Expt B) compared to on Oxyrrhis marina (Expt A) in the $\mu \mathrm{Z}$ treatments, most likely due to the higher ingestion rates on G. dominans (Fig. 1), as well as the relatively higher food concentration in this treatment (Table 3) and higher cellular C and $\mathrm{N}$ of $\mathrm{G}$. dominans (Table 2). A. tonsa urea release rates (0 to $4.1 \mathrm{ng}$ $\mathrm{N}$ ind.$^{-1} \mathrm{~h}^{-1}$ ) were lower compared to those measured by Miller \& Glibert (1998; 0 to $38 \mathrm{ng} \mathrm{N}$ ind.$\left.^{-1} \mathrm{~h}^{-1}\right)$. However, the portion of total $\mathrm{N}$ release as urea (0.6 to $6.6 \%$ in $\mu \mathrm{Z}, 13$ to $16 \%$ in DIATOM, and 32 to $59 \%$ in MIX; Fig. 3c) is similar to that measured by Miller \& Glibert (1998; 30 to $54 \%$ ) and higher than that for the copepod Pleuromamma xiphias (Steinberg et al. 2002; $21 \%$ ). These results reiterate the importance of organic $\mathrm{N}$ in nutrient remineralization.

Although $\mathrm{P}$ release rates for copepods are scarce in the literature, we did find similar $\mathrm{PO}_{4}{ }^{3-}$ release rates (mostly 1 to 2 , but reaching 11.5 ng $\mathrm{P}$ ind.$^{-1} \mathrm{~h}^{-1}$ ) compared to those for the similar-sized copepod Acartia australis (Ikeda et al. 2001; $1.3 \mathrm{ng} \mathrm{P}$ ind. ${ }^{-1} \mathrm{~h}^{-1}$ ), but higher release rates than those measured for the smaller cyclopoid copepod Oithona nana (Atienza et al. 2006; 0.34 to $0.37 \mathrm{ng} \mathrm{P}$ ind..$^{-1} \mathrm{~h}^{-1}$ ). When DOP release rates were detectable, they were higher than inorganic $P$ release rates and contributed 54 to $100 \%$ to the total $\mathrm{P}$ released (Fig. 4b), which was similar to the adult $A$. tonsa DOP release determined by Hargrave \& Geen $(1968 ; 74 \%)$. Zooplankton nutrient release experiments, specifically in marine environments, typically ignore P. Our results emphasize the importance of including zooplankton-mediated $\mathrm{P}$ release into nutrient budgets, especially in P-limited environments that depend on remineralization processes as the primary source of $\mathrm{P}$.

\section{Potential diatom nutrient uptake}

Nutrient uptake by diatoms likely occurred during incubations, as evidenced by declines in $\mathrm{NH}_{4}{ }^{+}$and urea concentrations from $T_{0}$ to $T_{24 \mathrm{~h}}$ in the DIATOM controls. Although this uptake was not directly measured in our experiments using labeled isotope techniques, the calculation for copepod nutrient release rate (Eq. 2) does incorporate these nutrient declines in the controls (uptake) in the term $\Delta C_{\mathrm{c}}$.

\section{Effect of diet on release rates}

The highest copepod DOC, $\mathrm{NH}_{4}{ }^{+}$, and TDN release rates occurred while feeding carnivorously. The lowest release rates occurred while feeding omnivorously, perhaps due to higher copepod $\mathrm{C}$ and $\mathrm{N}$ gross growth efficiencies (GGE) in the mixed diet. GGE is defined as the portion of nutrients from the ingested food delegated to growth and reproduction. A higher GGE for C and $\mathrm{N}$ would result in higher copepod egg production rates (EPR), increased biosynthesis (retention) of nutrients, and thus lower metabolic excretion of dissolved $\mathrm{C}$ and N. We did not measure EPR in the present study; however, previous studies support the idea that a mixed diet comprised of phytoplankton and microzooplankton results in higher EPR. Acartia tonsa copepods exhibited highest EPR and egg hatching success in treatments that included a mixed diet of Oxyrrhis marina and the alga Isochrysis galbana (Kleppel \& Burkart 1995). Stoecker \& Egloff (1987) reported $25 \%$ higher EPR for A. tonsa, and Bonnet \& Carlotti (2001) reported 3- to 7 -fold higher EPR and survival rates for Centropages typicus, when ciliates were mixed with a phytoplankton diet compared to an exclusively algal diet. Additionally, A. tonsa convert ingested food to eggs more efficiently in mixed diets, compared to exclusively algal and exclusively microzooplankton diets (Kleppel et al. 1998). These results were not confirmed by Ederington et al. (1995) or by Dam \& Lopes (2003). We believe this is due to their use of the bacterivorous ciliates Pleuronema sp. and Uronema sp., respectively, as this microzooplankton food source for copepods may either lack, or contain insufficient, fatty acids, including EPA and DHA (Ederington et al. 1995, Dam \& Lopes 2003). The heterotrophic dinoflagellates Oxyrrhis marina and Gyrodinium dominans (maintained on an algal diet of Dunaliella tertiolecta) used in our experiments, however, have previously been shown to be nutritionally beneficial to copepod growth, egg production, and egg hatching success (Klein Breteler et al. 1999, Tang \& Taal 2005) due to their high EPA and DHA contents.

The idea of higher GGE and higher egg production in the mix diet also suggests that this diet may be more balanced than either of the mono-diets, as a higher consumer-resource composition imbalance results in a lower consumer GGE (Sterner \& Elser 2002). Addition- 
ally, imbalances in diet could create differential assimilation patterns in order for the copepod to regulate synthesis of nutrients to match its needs, thus resulting in differential catabolism and eventual release of $\mathrm{C}, \mathrm{N}$, and P (Sterner \& Elser 2002).

Although gut transit time, egestion rate, and assimilation efficiency (AE) were not measured in our study, variability in these processes may have occurred in copepods feeding on the different diets. For instance, Acartia clausi copepods exhibited longer gut transit times, and Temora stylifera had lower egestion rates, while feeding on dinoflagellates compared to diatoms, the latter of which typically have lower molecular complexity (Ianora et al. 1995, Tirelli \& Mayzaud 2005). These studies suggest that copepods feeding on a more complex diet (i.e. more proteins, carbohydrates, lipids, etc.) may need a longer time to metabolize their food. This may have caused lower copepod nutrient release rates in the MIX treatment compared to the mono-diet treatments. However, if gut transit times or AE were solely a function of food molecular complexity, then nutrient release rates by copepods feeding on dinoflagellates in the $\mu \mathrm{Z}$ treatment would also be higher than those in the DIATOM treatment, and this did not occur in our study.

The differences in $\mathrm{P}$ release rates between treatments may be a result of variable food P composition. TDP release rates were highest in the microzooplankton diet, followed by the mixed diet, and lowest in the diatom diet, and DOP was only detectable in treatments containing microzooplankton prey. We did not measure particulate P contents in our food items, and there are no published data on P content in microzooplankton. Compared to algae, however, dinoflagellates have a larger genome (Raven 1994) and much higher amounts of DNA in their nucleus (Rizzo 1987). Because DNA is rich in P (Sterner \& Elser 2002), the higher release rates of $\mathrm{P}$ in our microzooplankton prey treatments could be a result of higher DNA contents in these heterotrophic dinoflagellates compared to Thalassiosira weissflogii diatoms.

\section{Possible behavioral effects on release rates}

Variations in nutrient release rates could also be due to copepods exerting different feeding behaviors on the 3 diets. Omnivorous copepods quickly hop and seize microzooplankton prey in 'ambush mode', generate continuous feeding currents in the more passive 'suspension mode' for non-motile phytoplankton food including diatoms, and exhibit prey-switching behavior when feeding on a mixed diet (Kiørboe et al. 1996). Although the energetic costs of each feeding mode have not been directly determined, the copepod
Metridia pacifica displays slower swimming speeds and fewer high-speed bursts when feeding on an exclusively phytoplankton diet compared to a more active feeding mode with frequent high-speed bursts when feeding on a carnivorous diet of Artemia sp. nauplii (Wong 1988). If more energy is expended by copepods feeding in the ambush mode compared to suspension mode, then nutrient release rates would also be higher in the ambush mode. This hypothesis is supported by our results: highest copepod DOC and TDN release rates while feeding on microzooplankton and lower release rates while feeding on diatoms (when copepods are likely feeding mainly in suspension mode) and on the mixed diet (where the energetic cost of ambush feeding is potentially cut by $50 \%$ ), as well as the release of DOP only in the treatments containing microzooplankton. Future research is needed in order to determine the energetic costs of feeding behaviors and their potential effects on copepod nutrient release.

\section{Microzooplankton and nutrient release}

The nutrient release directly from the heterotrophic dinoflagellate prey in the $\mu \mathrm{Z}$ treatment was investigated by calculating the change in nutrients in these control bottles during incubation (using the term $\Delta C_{\mathrm{c}}$ in Eq. 2). The only detectable positive release calculated in any control was $\mathrm{PO}_{4}{ }^{3-}$ release by Oxyrrhis marina in Expt A. The $\mathrm{PO}_{4}{ }^{3-}$ release by $O$. marina was significantly lower than that released by the copepods ( $p<$ 0.05); however, it most likely contributed to the lower calculated $\mathrm{PO}_{4}{ }^{3-}$ release (Eq. 2) by copepods feeding on $O$. marina (Expt A) compared to those feeding on Gyrodinium dominans (Expt B). Due to the negligible contribution of DOC, $\mathrm{NH}_{4}{ }^{+}$, and, in Expt $\mathrm{B}, \mathrm{PO}_{4}{ }^{3-}$ from the heterotrophic dinoflagellates in the present study, we infer that the elevated release of these nutrients in the $\mu \mathrm{Z}$ treatments came directly from the copepods.

\section{Inorganic versus organic $\mathbf{N}$ release}

Relative to inorganic $\mathrm{N}$ release, urea release rates were higher and accounted for a higher proportion of TDN released while copepods fed on a mixed diet. This could be due to the preferential metabolism of nucleic acids (RNA, DNA) via the uricogenesis/ureogenesis pathways of which urea is the primary byproduct (Regnault 1987). Ammonia formation, on the other hand, is the major byproduct of the catabolism of amino acids (Regnault 1987). Reasons for preferential metabolism of certain molecules over others, as related to zooplankton diet are, however, unclear and have not been reported. As discussed above, it is possible that 
the mixed diet is more balanced and allows higher efficiency in metabolizing nucleic acids as opposed to the other 2 mono-diets. Variability in the types of $\mathrm{N}$ released could also be due to differences in release processes. Both urea and $\mathrm{NH}_{4}{ }^{+}$can be released from the copepod body via simple diffusion across membrane surfaces (Pandian 1975, Bidigare 1983). However, while $\mathrm{NH}_{4}{ }^{+}$is rapidly released to avoid its toxic properties, urea has a slower diffusive property compared to $\mathrm{NH}_{4}{ }^{+}$, and thus disperses more slowly through the membranes (Pandian 1975). Thus, if copepods feeding on the mixed diet are efficiently retaining $\mathrm{N}$ for growth and reproduction, then a higher portion of the $\mathrm{N}$ that is being released may be the passive leakage of urea. Conversely, if copepods feeding on the mono-diets are not efficiently retaining $\mathrm{N}$, then more $\mathrm{NH}_{4}{ }^{+}$may be actively released. Diffusion of $\mathrm{NH}_{4}{ }^{+}$and urea are most likely short-term processes and may not be reflected in release rates during the $24 \mathrm{~h}$ incubation.

\section{Stoichiometry of nutrient release}

Copepod molar DOC:urea nitrogen release ratios were well above the classic Redfield C:N ratio (6.6); however, when all forms of released $\mathrm{N}$ and $\mathrm{P}$ were accounted for, molar DOC:TDN and TDN:TDP release ratios were either lower than or close to Redfield ratios (6.6 and 16, respectively). Non-Redfield remineralization has been shown for a variety of diel-migrating zooplankton taxa in the Sargasso Sea: DOC:DON (range from 5.1 to 14.9 ), DIC:DIN (6.1 to 12.6), and DIN:DIP (6.1 to 15.7) (Steinberg et al. 2002), as well as for Barents Sea zooplankton, which exhibit wide ranges of ratios of respiration and inorganic excretion: DIC:DIN (range 4 to 44 ) and DIN:DIP (2 to 45) (calculated from Table 3 in Ikeda \& Skjoldal 1989).

Released C:N and N:P ratios were also variable between treatments. High molar DOC:urea release ratios in the $\mu \mathrm{Z}$ treatment were a result of the low proportion of urea release (as the total percentage of $\mathrm{N}$ ), which ranged from 0.6 to $6.6 \%$. DOC:urea release ratios, as well as the proportion of urea release in the DIATOM and MIX treatments (5.1 to 14.9 and 21 to $40 \%$, respectively) more closely resembled those found by Steinberg et al. (2002). The higher TDN:TDP ratio of the released products in the DIATOM treatment was most likely due to lower P contents in the diatoms relative to microzooplankton prey items, similar to those found for Daphnia feeding on P-limited prey items (Frost et al. 2004). Additionally, we cannot discuss stoichiometric imbalances without considering predator (copepod) P content, which, if variable between treatments, could potentially explain the different TDN: TDP release ratios. We did not measure copepod $\mathrm{P}$ content in our experiments; however, Walve \& Larsson (1999) found that while Acartia sp. C and N contents were stable, their $\mathrm{P}$ content (and N:P) varied greatly. These variations were seasonal, as were those for $A$. clausii C:P and N:P according to Gismervik (1997b), and thus may also be a function of copepod diet composition as well as differences in growth rate (changes in P-rich DNA and RNA). Additional research is required to attain a more complete understanding of how predator and prey $\mathrm{P}$ content affects copepod P release rates and organic and inorganic N:P release ratios.

Stoichiometric theoretical models that have been implemented to further understand consumer-driven nutrient recycling processes all agree that the stoichiometry of nutrients released from zooplankton is mainly a function of both food and grazer elemental composition (Sterner 1990, Elser \& Urabe 1999, Touratier et al. 2001). However, our results show the uncoupling of copepod ingestion and nutrient release rates, as well as variable release rates of DOC, and dissolved organic and inorganic N and $\mathrm{P}$, on different food types (phytoplankton vs. microzooplankton vs. mix), but with similar prey C:N. This is most likely because these aforementioned models are limited to excretion, and do not incorporate sloppy feeding and egestion/fecal pellet leaching. Thus, stoichiometric models based exclusively on predator and prey $\mathrm{C}: \mathrm{N}$ and $\mathrm{N}: \mathrm{P}$ ratios may not be adequate in determining stoichiometry of total nutrient release, especially when considering variability in diet.

Finally, differences in the stoichiometry may also be explained by other aspects of food composition (i.e. relative amounts of complex lipids vs. simple protein or amino acid contents, differential nucleic acid content), which may have affected the rate at which $\mathrm{C}, \mathrm{N}$, and $\mathrm{P}$ were individually metabolically processed, digested, and released, creating differential C:N and N:P release ratios. Extended models, which incorporate dietary constituents such as essential fatty acids (Anderson \& Pond 2000), prey selectivity (Mitra \& Flynn 2006), and digestion efficiency/gut transit time (Mitra \& Flynn 2007), may be more appropriate when copepods feed on a diversity of food items.

\section{CONCLUSIONS}

We have shown that copepod nutrient release rates, composition, and stoichiometry are significantly affected by feeding strategy. In particular, we have revealed key nutrient release differences in copepods feeding omnivorously compared to those feeding on mono-diets of either phytoplankton or microzooplankton. While we could not directly distinguish the source(s) of variable nutrient release, we provide a 
black box view of zooplankton nutrient release as a function of diet and discuss multiple factors that may drive nutrient release variability. Including mixed diets of phytoplankton and microzooplankton should be an important component of future studies examining copepod metabolism and digestion, growth efficiency, and inorganic and organic nutrient release. Differences in these processes with diet, as well as the proportion of time copepods spend feeding herbivorously, carnivorously, and omnivorously, need to be accounted for in order to estimate the quantity, quality, and stoichiometry of regenerated nutrients available for the growth and metabolism of phytoplankton and heterotrophic bacteria, and to better model the role of zooplankton in ocean nutrient and $\mathrm{C}$ budgets.

Acknowledgements. We are grateful to J. Cope, E. M. Yam, S. E. Wilson, B. R. Eden, and V. S. Saba for their help with field work and conducting the experiments, and Q. Roberts, R. H. Condon, and J. C. Dreyer for their aid in sample analysis. We thank W. O. Smith, Jr. for the use of his elemental combustion analyzer to measure carbon and nitrogen content. Thanks also to K. W. Tang and D. K. Stoecker for their valuable comments that aided us in manuscript preparation. The research described in the present paper has been funded in part by the Biocomplexity Program of the US National Science Foundation (OCE-0221825) and also the United States Environmental Protection Agency (EPA) under the Science to Achieve Results (STAR) Graduate Fellowship Program. The EPA has not officially endorsed this publication, and the views expressed herein may not reflect the views of the EPA. This manuscript is Contribution No. 3026 of the Virginia Institute of Marine Science, The College of William and Mary.

\section{LITERATURE CITED}

Anderson TR, Pond DW (2000) Stoichiometry theory extended to micronutrients: comparison of the roles of essential fatty acids, carbon, and nitrogen in the nutrition of marine copepods. Limnol Oceanogr 45:1162-1167

- Andersson MGI, van Rijswijk P, Middelburg JJ (2006) Uptake of dissolved inorganic nitrogen, urea and amino acids in the Scheldt estuary: comparison of organic carbon and nitrogen uptake. Aquat Microb Ecol 44:303-315

Atienza D, Calbet A, Saiz E, Alcaraz M, Trepat I (2006) Trophic impact, metabolism, and biogeochemical role of the marine cladoceran Penilia avirostris and the co-dominant copepod Oithona nana in NW Mediterranean coastal waters. Mar Biol 150:221-235

Azam F, Fenchel T, Field JG, Gray JS, Meyer-Reil LA, Thingstad F (1983) The ecological role of water-column microbes in the sea. Mar Ecol Prog Ser 10:257-263

Besiktepe S, Dam HG (2002) Coupling of ingestion and defecation as a function of diet in the calanoid copepod Acartia tonsa. Mar Ecol Prog Ser 229:151-164

Bidigare RR (1983) Nitrogen excretion by marine zooplankton. In: Carpenter EJ, Capone DG (eds) Nitrogen in the marine environment. Academic Press, New York, p 385-409

Bonnet D, Carlotti F (2001) Development and egg production in Centropages typicus (Copepoda: Calanoida) fed different food types: a laboratory study. Mar Ecol Prog Ser
224:133-148

Bratbak G (1985) Bacterial biovolume and biomass estimations. Appl Environ Microbiol 49:1488-1493

Broglio E, Jónasdóttir SH, Calbet A, Jakobsen HH, Saiz E (2003) Effect of heterotrophic versus autotrophic food on feeding and reproduction of the calanoid copepod Acartia tonsa: relationship with prey fatty acid composition. Aquat Microb Ecol 31:267-278

Broglio E, Saiz E, Calbet A, Trepat I, Alcaraz M (2004) Trophic impact and prey selection by crustacean zooplankton on the microbial communities of an oligotrophic coastal area (NW Mediterranean Sea). Aquat Microb Ecol 35:65-78

Bronk DA, Lomas MW, Glibert PM, Schukert KJ, Sanderson MP (2000) Total dissolved nitrogen analysis: comparisons between the persulfate, UV and high temperature oxidation methods. Mar Chem 69:163-178

Caron DA, Goldman JC (1990) Protozoan nutrient regeneration. In: Capriulo GM (ed) Ecology of marine protozoa. Oxford University Press, New York, p 283-306

CBP (Chesapeake Bay Program) (2000) Guide to living resources data. Chesapeake Bay Program, Annapolis, MD. Available at: www.chesapeakebay.net

Corner EDS, Head RN, Kilvington CC, Pennycuick L (1976) On the nutrition and metabolism of zooplankton. X. Quantitative aspects of Calanus helgolandicus feeding as a carnivore. J Mar Biol Assoc UK 56:345-358

Cotner JB, Wetzel RG (1992) Uptake of dissolved inorganic and organic phosphorus compounds by phytoplankton bacteria. Limnol Oceanogr 37:232-243

> Dam HG, Lopes RM (2003) Omnivory in the calanoid copepod Temora longicornis: feeding, egg production and egg hatching rates. J Exp Mar Biol Ecol 292:119-137

del Giorgio PA, Cole JJ (2000) Bacterial energetics and growth efficiency. In: Kirchman DL (ed) Microbial ecology of the oceans. Wiley-Liss, New York, p 289-325

Ederington MC, McManus GB, Harvey HR (1995) Trophic transfer of fatty acids, sterols, and a triterpenoid alcohol between bacteria, a ciliate, and the copepod Acartia tonsa. Limnol Oceanogr 40:860-867

Elser JJ, Urabe J (1999) The stoichiometry of consumer-driven nutrient recycling: theory, observations, and consequences. Ecology 80:735-751

Fessenden L, Cowles TJ (1994) Copepod predation on phagotrophic ciliates in Oregon coastal waters. Mar Ecol Prog Ser 107:103-111

Frost BW (1972) Effects of size and concentration of food particles on the feeding behavior of the marine planktonic copepod Calanus pacificus. Limnol Oceanogr 17:805-815

Frost PC, Xenopoulos MA, Larson JH (2004) The stoichiometry of dissolved organic carbon, nitrogen, and phosphorus release by a planktonic grazer, Daphnia. Limnol Oceanogr 49:1802-1808

Fukuda R, Ogawa H, Nagata T, Koike I (1998) Direct determination of carbon and nitrogen contents of natural bacterial assemblages in marine environments. Appl Environ Microbiol 64:3352-3358

Gifford DJ (1991) The protozoan-metazoan trophic link in pelagic ecosystems. J Protozool 38:81-86

Gifford DJ, Dagg MJ (1988) Feeding of the estuarine copepod Acartia tonsa Dana: carnivory vs. herbivory in natural microplankton assemblages. Bull Mar Sci 43:458-468

Gismervik I (1997a) Implications of zooplankton stoichiometry on distribution of $\mathrm{N}$ and $\mathrm{P}$ among planktonic size fractions. J Plankton Res 19:343-356

Gismervik I (1997b) Stoichiometry of some marine planktonic crustaceans. J Plankton Res 19:279-285

Goldman JC, Dennett MR (1991) Ammonium regeneration 
and carbon utilization by marine bacteria grown on mixed substrates. Mar Biol 109:369-378

Grasshoff K, Ehrhard M, Kremling K (1983) Methods of seawater analysis, 2nd edn. Verlag Chemie, Weinheim

Hargrave BT, Geen GH (1968) Phosphorus excretion by zooplankton. Limnol Oceanogr 13:332-342

Hasle GR (1978) The inverted microscope method. In: Sournia A (ed) Phytoplankton manual. UNESCO, Paris, p 88-96

Ianora A, Poulet SA, Miralto A (1995) A comparative study of the inhibitory effect of diatoms on the reproductive biology of the copepod Temora stylifera. Mar Biol 121: 533-539

Ikeda T, Skjoldal HR (1989) Metabolism and elemental composition of zooplankton from the Barents Sea during early Arctic summer. Mar Biol 100:173-183

Ikeda T, Kanno Y, Ozaki K, Shinada A (2001) Metabolic rates of epipelagic marine copepods as a function of body mass and temperature. Mar Biol 139:587-596

Jumars PA, Penry DL, Baross JA, Perry MJ, Frost BW (1989) Closing the microbial loop: dissolved carbon pathway to heterotrophic bacteria from incomplete ingestion, digestion and absorption in animals. Deep-Sea Res I 36:483-495

Kiørboe T, Mohlenberg F, Hamburger K (1985) Bioenergetics of the planktonic copepod Acartia tonsa: relation between feeding, egg production and respiration, and composition of specific dynamic action. Mar Ecol Prog Ser 26:85-97

Kiørboe T, Saiz E, Viitasalo M (1996) Prey switching behavior in the planktonic copepod Acartia tonsa. Mar Ecol Prog Ser 143:65-75

Kirchman DL (2000) Uptake and regeneration of inorganic nutrients by marine heterotrophic bacteria. In: Kirchman DL (ed) Microbial ecology of the oceans. Wiley-Liss, New York, p 261-288

Kirchman DL, Ducklow HW (1993) Estimating conversion factors for the thymidine and leucine methods for measuring bacterial production. In: Kemp PF, Sherr BF, Sherr EB, Cole JJ (eds) Handbook of methods in aquatic microbial ecology. Lewis Publishers, Boca Raton, FL, p 513-518

Klein Breteler WCM, Schogt N, Baas M, Schouten S, Kraay GW (1999) Trophic upgrading of food quality by protozoans enhancing copepod growth: role of essential lipids. Mar Biol 135:191-198

Kleppel GS, Burkart CA (1995) Egg production and the nutritional environment of Acartia tonsa: the role of food quality in copepod nutrition. ICES J Mar Sci 52:297-304

Kleppel GS, Burkart CA, Houchin L (1998) Nutrition and the regulation of egg production in the calanoid copepod Acartia tonsa. Limnol Oceanogr 43:1000-1007

Menden-Deuer S, Lessard EJ (2000) Carbon to volume relationships for dinoflagellates, diatoms, and other protist plankton. Limnol Oceanogr 45:569-579

Menden-Deuer S, Lessard EJ, Satterberg J (2001) Effect of preservation on dinoflagellate and diatom cell volume and consequences for carbon biomass predictions. Mar Ecol Prog Ser 222:41-50

Merrell JR, Stoecker DK (1998) Differential grazing on protozoan microplankton by developmental stages of the calanoid copepod Eurytemora affinis Poppe. J Plankton Res 20:289-304

Miller CA, Glibert PM (1998) Nitrogen excretion by the calanoid copepod Acartia tonsa: results of mesocosm experiments. J Plankton Res 20:1767-1780

Miller CA, Landry MR (1984) Ingestion-independent rates of ammonium excretion by the copepod Calanus pacificus. Mar Biol 78:265-270

> Miller CA, Roman MR (2008) Effects of food nitrogen content and concentration on the forms of nitrogen excreted by the calanoid copepod, Acartia tonsa. J Exp Mar Biol Ecol 359:11-17

Mitra A, Flynn KJ (2006) Accounting for variation in prey selectivity by zooplankton. Ecol Modell 199:82-92

Mitra A, Flynn KJ (2007) Importance of interactions between food quality, quantity, and gut transit time on consumer feeding, growth, and trophic dynamics. Am Nat 169: 632-646

Møller EF (2005) Sloppy feeding in marine copepods: preysize-dependent production of dissolved organic carbon. J Plankton Res 27:27-35

Møller EF (2007) Production of dissolved organic carbon by sloppy feeding in the copepods Acartia tonsa, Centropages typicus, and Temora longicornis. Limnol Oceanogr 52:79-84

Montagnes DJS, Berges JA, Harrison PJ, Taylor FJR (1994) Estimating carbon, nitrogen, protein, and chlorophyll a from volume in marine phytoplankton. Limnol Oceanogr 39:1044-1060

Pandian JJ (1975) Mechanisms of heterotrophy. In: Kinne O (ed) Marine ecology, Vol 2. Wiley, New York, p 179-188

Parsons RT, Maita Y, Lalli CM (1984) A manual of chemical and biological methods for seawater analysis. Pergamon Press, New York

Peltzer ET, Fry B, Doering PH, McKenna JH, Norrman B, Zweifel UL (1996) A comparison of methods for the measurement of dissolved organic carbon in natural waters. Mar Chem 54:85-96

> Price NM, Harrison PJ (1987) Comparison of methods for the analysis of dissolved urea in seawater. Mar Biol 94: 307-317

Protocols for the Joint Global Ocean Flux Study (JGOFS) Core Measurements (1994) SCOR Manual and guides, 29. UNESCO, Paris

Raven JA (1994) Why are there no picoplanktonic $\mathrm{O}_{2}$ evolvers with volumes less than $10^{-19} \mathrm{~m}^{3}$ ? J Plankton Res 16: $565-580$

> Regnault M (1987) Nitrogen excretion in marine and freshwater Crustacea. Biol Rev Camb Philos Soc 62:1-24

Rizzo PJ (1987) Biochemistry of the dinoflagellate nucleus. In: Taylor FJR (ed) The biology of dinoflagellates. Blackwell Scientific, Oxford, p 143-173

Sharp JH (2002) Analytical methods for total DOM pools. In: Hansell DA, Carlson CA (eds) Biogeochemistry of marine dissolved organic matter. Academic Press, Boston, MA, p 35-58

Sherr BF, Sherr EB, Berman T (1983) Grazing, growth and ammonium excretion rates of a heterotrophic microflagellate fed with four species of bacteria. Appl Environ Microbiol 45:1196-1201

Steinberg DK, Saba GK (2008) Nitrogen consumption and metabolism in marine zooplankton. In: Capone DG, Bronk DA, Mulholland MR, Carpenter EJ (eds) Nitrogen in the marine environment, 2nd edn. Academic Press, Boston, MA, p 1135-1196

Steinberg DK, Goldthwait SA, Hansell DA (2002) Zooplankton vertical migration and the active transport of dissolved organic and inorganic nitrogen in the Sargasso Sea. DeepSea Res I 49:1445-1461

Sterner RW (1990) The ratio of nitrogen to phosphorus resupplied by herbivores: zooplankton and the algal competitive arena. Am Nat 136:209-229

Sterner RW, Elser JJ (2002) Ecological stoichiometry: the biology of elements from molecules to the biosphere. Princeton University Press, Princeton, NJ

Stoecker DK, Capuzzo JM (1990) Predation on protozoa: its importance to zooplankton. J Plankton Res 12:891-908 
Stoecker DK, Egloff DA (1987) Predation by Acartia tona Dana on planktonic ciliates and rotifers. J Exp Mar Biol Ecol 110:53-68

Strom SL, Benner R, Ziegler S, Dagg MJ (1997) Planktonic grazers are a potentially important source of marine dissolved organic carbon. Limnol Oceanogr 42:1364-1374

Tang KW, Taal M (2005) Trophic modification of food quality by heterotrophic protists: species-specific effects on copepod egg production and egg hatching. J Exp Mar Biol Ecol 318:85-98

Tang KW, Jakobsen HH, Visser AW (2001) Phaeocystis globosa (Prymnesiophyceae) and the planktonic food web: feeding, growth and trophic interactions among grazers. Limnol Oceanogr 46:1860-1870

Tirelli V, Mayzaud P (2005) Relationship between functional response and gut transit time in the calanoid copepod Acartia clausi: role of food quantity and quality. J Plankton

Editorial responsibility: Peter Verity,

Savannah, Georgia, USA
Res 27:557-568

Titelman J, Riemann L, Holmfeldt K, Nilsen T (2008) Copepod feeding stimulates bacterioplankton activities in a low phosphorus system. Aquat Biol 2:131-141

Touratier F, Field JG, Moloney CL (2001) A stoichiometric model relating growth substrate quality (C:N:P ratios) to $\mathrm{N}: \mathrm{P}$ ratios in the products of heterotrophic release and excretion. Ecol Modell 139:265-291

Utermöhl H (1931) Neue Wege in der quantitative Erfassung des Planktons (mit besonderer Berücksichtigung des Ultraplanktons). Verh Int Ver Theor Angew Limnol 5:567-596

Walve J, Larsson U (1999) Carbon, nitrogen and phosphorus stoichiometry of crustacean zooplankton in the Baltic Sea: implications for nutrient cycling. J Plankton Res 21: 2309-2321

Wong CK (1988) The swimming behavior of the copepod Metridia pacifica. J Plankton Res 10:1285-1290

Submitted: November 11, 2008; Accepted: April 21, 2009 Proofs received from author(s): June 27, 2009 